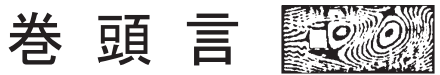

\section{防災学術連携体の発足と活動 \\ 一防災減災とより良い災害復興のために必要な多くの学術分野の連携一 Introduction of Japan Academic Network for Disaster Reduction}

\author{
和田 章*
}

Akira WADA

\section{「絶えない自然災害」}

人類の長い歴史の中で世界，日本，そして社会は変化 していく。科学技術は進化し，文明・文化も変化する。 これに比べると一人の人生は瞬間のように短いが，数十 年の間に楽しいことと辛いことが多く起こる。楽しいこ とは良いとして，辛いことや心配は個人，家族，社会， 国や世界に山積している。身近な心配は, 日々の生活, 仕事, 活動の中に多くあり, 子供の将来, 親の病気, 自 らの老後など，頭から離れない。

大きな心配として，人間の起こす戦争があるが，これ は人間が起こすことだから，戦争の起きない世界を作る 努力を惜しんではならない。もう一つの大きな心配は, 21 世紀になっても日本だけでなく世界で起きている自然 災害である。

\section{「避けられない自然の猛威と災害」}

地球の半径は $6370 \mathrm{~km}$ ，人類はこの $1 / 600$ 程度の表面近 くの上下 $10 \mathrm{~km}$ ほどの天地のはざまに影響を受けつつ生 きている。大地震や火山の爆発は地中のマントルの対流 を原動力とした地款の動きが起こす。これらは地球の営 みであり止めることはできない。ジャンボジェットの飛 ぶ高さは $10 \mathrm{~km}$, 積乱雲の高さも $10 \mathrm{~km}$ に及び, 台風, 強 風, 竜巻, 干ばつ, 豪雨, 豪雪は大気の動きと海から蒸 発する水蒸気の動きによって起こる。地球温暖化の影響
はこれらの気候変動を激しくしていることは間違いなく， 1972 年にローマクラブが発表した「成長の限界」, 米国 の元副大統領アル・ゴアが 2006 年に発表した「不都合な 真実」などで指摘されているように，荒くなる気象を穏 やかにすることも容易ではない。結果的に, 自然災害を 減じるためには, 自然の猛威を受ける側の人間社会を強 くすることしかない。

\section{「危険のない適地の選択」}

日本のように山地が多く, 平野の少ないところでは難 しいことであるが，第一に重要なことは，住宅，村やま ち，都市をできる限り自然の猛威の影響を受けにくいと ころに作ることである。2011 年の東日本大震災の大津波 による大災害, 千葉の埋め立て地に開発された住宅地域 に起きた大規模な液状化，2018 年の西日本豪雨による大 災害などは，適地でないところに人々の生活と活動の場 を広げた失敗である。強風に対して弱い地形や地域もあ ると思う。ただ，すでに述べたように，人々には日々の 活動があり，多くの悩みもあり，災害を減じることだけ が目的で生きているわけではないから，危険性のある地 に村やまちができてしまう。これを止めることは，やは り容易ではなく, 自然の猛威は人々の活動・生活の場に 襲ってきて自然災害が起こってしまう。 


\section{「構造物の破壊」}

適地の選択の次に重要なことは, 丈夫で長持ちするイ ンフラと建築により，村やまち，そして都市を強く構築 寸ることである。国ごと地域ごとに, 強風, 豪雨, 豪雪, 地震動などの自然の猛威を想定し, その大きさと発生頻 度を考慮して，具体的に構造物は建設されていく。この とき，予算の制約もあり，構造物にはあるレベルの強さ を設定せざるをえず，絶対に壊れない構造物を作ること はできない。知りえない自然現象もあり，設定を超える 自然の猛威が襲うこともある。重社て技術の未熟と過信, そして無理な適用もあり，構造物は壊れてしまう。

濃尾地震（1891）の橋梁などの破壊から西日本豪雨 （2018）の堤防決壊まで，約 130 年の間に，構造物の破 壊による自然被害は止まっていない。この中で東日本大 震災（2011）の原子力発電所の爆発には, 特に反省す心 きことが多い。

\section{「防災と減災」}

このように考えると，残念ではあるが，自然災害は将 来にも起こると言わざるを得ない。東日本大震災のあと に言われたことであるが, 稀に起こる自然の猛威には「災 害が起きない」ことを目指寸「防災」，きわめて稀に起 こる自然の猛威には「災害は受けるが人命を守る」こと を目指寸「減災」の二つの考え方が取り入れられた。

このことを陽に示しているのは, 日本の建築物の耐震 設計基準である。関東大震災（1923）の次の年に市街地 建築物法の規則として示された世界で初めての耐震基隻 のころから, 而震設計は実際に起きた地震動より小さな 地震力で行い，大地震には倒壊しなければ良いとの考え 方がある。1981 年に施行された新而震設計法, 2000 年に 改正された建築基準法でも, 稀に起こる中小地震には無 被害を目指寸「防災」, きわめて稀に起こる大地震には 人命を守るために建築物の倒壊は防ぐが，傾いてしまい 地震後に使えなくなることを許容する「減災」の考え方 で進められている。きわめて稀，つまり数百年に一度し か起こらない大地震に対して, 絶対に壊れない建築物を 作れと市民に強要できないことが根拠となっている。背 景には日本国憲法第29条の「財産権を侵してはならない」 がある。

結果として, 日本では徹底した防災は求められておら ず, 95 年前から減災を求めてきたと言える。結果として, 次の自然災害は日本のどこかで必ず起こる。

世界では地震の起きにくいところが多く, 超高層建築 の設計は風荷重によって決まっている。そして, 構造物
が受ける強風の影響は地震に比べ長時間に亘るため，基 本的に強風時の構造物に塑性変形を許容していない。こ のためと思うが，強風を受けて超高層ビルが倒壊したこ とはなく, 2018 年 9 月初めに襲った第 21 号台風でも大阪 で起きたが, 非構造部材の飛翔, 強風時の構造物の長時 間の摇れ，中に暮らす人々の居住性の方が問題になるよ うに思う。

\section{「災害後の救助、救命、緊急医療」}

熊本地震 (2016) では直後に約 50 名の人々が亡くなり, 西日本豪雨災害（2018）では亡くなった方，行方不明の 方を合わせて 230 名を超えている。21 世紀の今,「減災」 ですら満たされていないことは残念である。地震の予知 は不可能であるが，台風，豪雨，強風など気象の予想精 度は日々高まっている。風水害の発生する前に避難する ことにより，人命を守ることに努力しなければならない。 災害発生後には, 救助活動に向かう人々, 災害後の緊 急医療の活動が重要である。ここに全てを書くことはで きないが，道路や鉄道の不通，住宅の破壊，生活品，食 料, 水や電気の供給不能などにより，平常では便利な社 会が一変して不便な社会に変わる。多くの災害廃棄物な じ普段にはない大きな問題も発生する。発生直後に各地 の建設会社の活動が始まり, 消防団, 警察や自衛隊の活 動によって社会は少しずつ安定化に向かう。

\section{「災害の辛さの再分配、復旧と復興」}

自然災害を防止することができない現状では，災害後 を考える必要があり，災害の辛さを受けてない人々との あいだで分け合う仕組みが必要である。懸命なボランテ イア活動にも頭がさがる。

復旧・復興は, 日本では国の予算で補うことが多いが, 欧米では，多くの辛さを保険制度が補っている。中国で は多くの大きな都市が互いに保険制度をつくり，自然災 害を受けた都市の復旧・復興をこの保険金で補うことが 準備されている。どの国でも，防止できない自然災害の あと，地域や人々の復旧と復興が始まる。

\section{「分野を超えた学術連携の必要性」}

台風, 強風, 地震, 火山の爆発, 気象変動, 豪雨, 豪 雪などの自然の猛威に関する理学分野の研究, 地理から 地質と地盤を扱う分野, 人々の暮らし，産業の場所を考 える都市計画やまち作りに関する研究, 防波堤・防潮堤, ダムや河川, 橋梁, 高速道路網, 鉄道網を扱う土木工学 分野, 住宅から多くの建築物を設計し建設する建築分野, 
エネルギー問題を扱う分野，災害発生後の人々の活動を 扱う研究分野, 緊急医療之看護の分野, 被災地の人々の 心の問題, まちや都市の復旧復興に関わる分野，これら を総合的に考える法制上の問題，経済問題，政治，行政 など, 災害の軽減と災害復興には多くの分野の研究が行 われている。

\section{「防災学術連携体の創設」}

阪神・淡路大震災（1995）のあと, 工学分野の 6 つの 学会が合同報告書を出版し, 分野を超えた学術連携の必 要性を訴え, その後日本地震工学会が発足した。この活 動のさらなる広がりはなかったが, 東日本大震災 (2011) を3 月 11 日に受け, 即座に日本学術会議の土木工学・建 築学委員会が幹事役となり「東日本大震災の総合対応に 関する学協会連絡会」が設立され，30 学会による学際連 携が進められてきた。

2016 年 1 月に, この取組みをさらに発展させ，地震や 津波だけでない自然災害への防災減災・災害復興を対象 に, より広い分野の学会の参画を得ながら, 研究成果を
災害軽減に役立てるため「防災学術連携体」が創設され た。

\section{「防災学術連携体の活動」}

「防災学術連携体」には現在日本風工学会, 土木学会, 日本建築学会など 56 の学会が参加し, 日本学術会議には 「防災減災学術連携委員会」が設立され，両者の協力に より意義ある連携活動が進められている。内閣府に設け られた防災推進国民会議には学術分野からの代表として この $2 つ の$ 組織が参加し, 今年で 3 回目となる防災推進 国民大会では大きな市民向けの催しを開いている。

一人の人間の「からだ」は全体でネットワークを構成 している。西洋医学では, 肺, 心臓, 肝臟のように臓器 ごとにその健全性や機能を分析し, 病気を治そうとする。 東洋医学では, すべての臓器は互いに関係し合っている ことを前提に，病気を治そうとする。防災減災，より良 い災害復興のためには学問がバラバラに活動していたの では対処できない。東洋医学のように，すべての学問が 坦根を取り払い，互いを知って連携して活動する必要が ある。災害の発生を皆無にすることは難しいが，災害を 軽減する努力を続けなくてはならない。

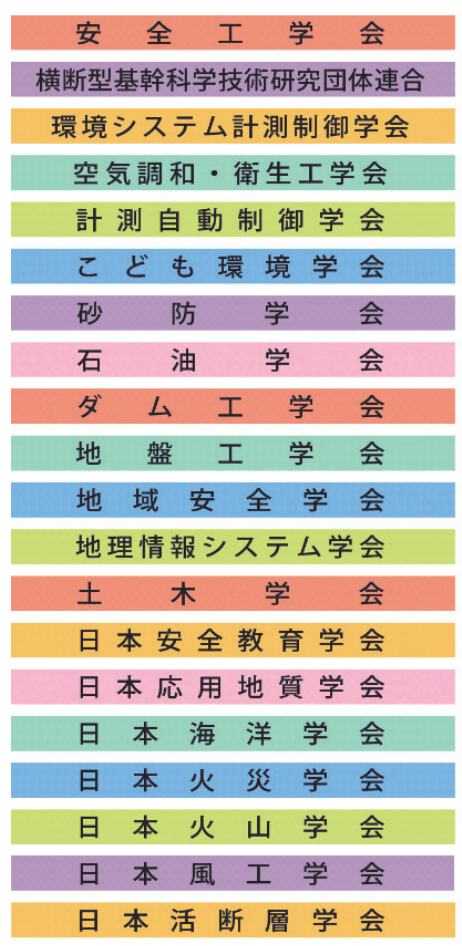

防災学術連携体
日本看護系学会協議会 日本機械学会 日本気象学会 日本救急医学 会 日本計画行政学会 日本建 築 学 会 日本原子力学会 日本公衆衛生学会 日本古生物 学 会

\section{日 本 学術会 議} SCIENCE COUNCIL OF JAPAN

日本コンクリートエ学会 日本災害医学会 日本災害看護学会 日本災害情報学会 日本災害復興学会 日本自然災害学会 日 本森林学 会

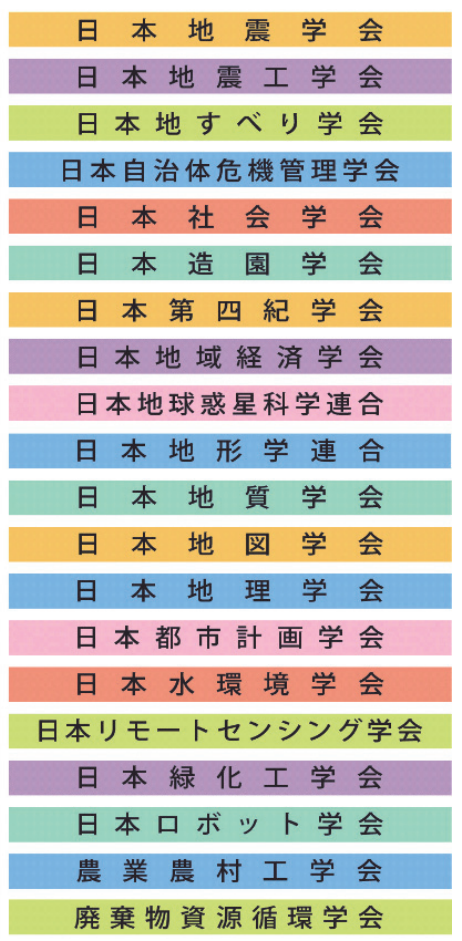

·防災減災·災害復興に関する学会ネットワーク

-日本学術会議防災減災学術連携委員会とともに活動

• 防災関連の学術総合ポータルサイト https://janet-dr.com/ 